\title{
Capsaicinoid and Capsinoids as an Ergogenic Aid: A Systematic Review and the Potential Mechanisms Involved
}

\author{
Vilton E.L. de Moura e Silva, Jason M. Cholewa, François Billaut, Ralf Jäger, Marcelo C. de Freitas, \\ Fabio S. Lira, and Fabrício E. Rossi
}

\begin{abstract}
Context: Capsaicinoids and capsinoids (CAP) are natural substances found primarily in chili peppers and other spicy foods that agonize the transient receptor potential vanilloid-1 in the mouth, stomach, and small intestine. Several studies have shown CAP to be a potential antiobesity agent and to exhibit an analgesic effect in both rodents and humans. However, there is no scientific consensus about the effects of CAP on physical exercise performance and its physiological mechanisms of action. Purpose: This systematic review aimed to better elucidate the effects of CAP compounds as ergogenic aids and to discuss underlying mechanisms of action by which this supplement may potentially enhance endurance performance and muscular strength. Conclusions: Among 22 studies included in the review, 14 examined the effects of capsaicinoid or capsinoid compounds on endurance and resistance exercise performance in animals, with 9 studies showing benefits on performance. In humans, 8 studies were included: 3 demonstrated significant acute endurance benefits and 2 showed acute resistance exercise performance benefits compared with a placebo condition. Therefore, while more mechanistic studies are necessary to confirm these outcomes in humans, the available scientific literature appears to suggest that these compounds could be considered an effective nutritional strategy to improve exercise performance.
\end{abstract}

Keywords: performance, endurance, strength, resistance exercise, supplementation, preworkout

Physical activities including endurance and resistance training programs are well-known strategies to improve cardiorespiratory fitness and muscular health according to the American College of Sports Medicine. ${ }^{1}$ Fitness enthusiasts and recreational and trained athletes seek to optimize the benefits induced by exercise through targeted nutrition including nutritional supplements that are widely consumed in order to enhance training outcomes. ${ }^{2}$

Capsaicinoids are the pungent compounds found primarily in chili peppers and other spicy foods. Capsaicin (trans-8-methyl-Nvanillyl-6-nonenamide) and dihydrocapsaicin (8-methyl-N-vanillylnonanamide) are among the most abundant capsaicinoids and are responsible for approximately $90 \%$ of total pungency. ${ }^{3,4}$ Orally administered capsaicin is rapidly absorbed in the various tissues,

(C) 2021 The Authors. Published by Human Kinetics, Inc. This is an Open Access article distributed under the terms of the Creative Commons Attribution 4.0 International License, CC BY 4.0, which permits unrestricted noncommercial and commercial use, distribution, and reproduction in any medium, provided the original work is properly cited, the new use includes a link to the license, and any changes are indicated. See http://creativecommons.org/licenses/by/4.0. This license does not cover any third-party material that may appear with permission in the article.

de Moura e Silva and Rossi are with the Immunometabolism of Skeletal Muscle and Exercise Research Group, Dept of Physical Education, Federal University of Piauí (UFPI), Teresina, Brazil; Rossi is also with the Graduation Program in Science and Health at the university. Cholewa is with the Dept of Exercise Physiology, University of Lynchburg, Lynchburg, VA, USA. Billaut is with the Dept of Kinesiology, Université Laval, Quebec City, QC, Canada. Jäger is with Increnovo LLC, Milwaukee, WI, USA. de Freitas is with the Dept of Nutrition, University of Western São Paulo (UNOESTE), Presidente Prudente, Brazil. Lira is with the Exercise and Immunometabolism Research Group, Post-Graduation Program in Movement Sciences, Dept of Physical Education, School of Technology and Sciences, São Paulo State University (UNESP), Presidente Prudente, Brazil. Rossi (fabriciorossi@ufpi.edu.br) is corresponding author. such as blood, liver, kidney, and intestine with highest concentration in blood and intestinal tissue at 1 hour, liver at 3 hours, and kidney at 6 hours. Absorption is a passive process that does not require an ATP investment, with variable amounts ranging from $50 \%$ to $90 \%$ being absorbed, depending on the tissue distribution and analytical method employed (thin-layer chromatography or high-performance liquid chromatography). ${ }^{5,6}$ Capsaicin concentration can be detected in plasma as soon as 10 minutes following administration, peaking at $\sim 47$ minutes, with a half-life in blood of $\sim 25$ minutes, and maximum plasma concentrations of $2.5 \pm 0.13 \mathrm{ng} \cdot \mathrm{mL}$ following a $26.6-\mathrm{mg}$ dose of capsaicin in gel capsules. ${ }^{7-9}$ The mode of oral delivery (gel capsules vs chewable delivery methods, and capsaicin vs a mix of capsinoids) may influence plasma availability and ergogenic effects. For example, Cross et $\mathrm{al}^{10}$ found significant acute benefits of a chewable capsaicin supplement on isokinetic knee extensor contractile performance, whereas Opheim and Rankin ${ }^{11}$ administered a commercially available cayenne pepper supplement and did not find an improvement in repeated-sprint tests. While a considerable amount of research has been done examining differences in bioavailability of various delivery methods of CAP when administered transdermally, ${ }^{12}$ there are no studies to our knowledge that have investigated bioavailability or pharmacokinetics of oral ingestion.

Capsinoids, which include capsiate (4-hydroxy-3-methoxybenzyl [E]-8-methyl-6-nonenoate), dihydrocapsiate, and nordihydrocapsiate, on the other hand, are nonspicy compounds. Capsinoids are chemical analogs of capsaicin, a component of a sweet pepper called "CH-19 Sweet" that is highly concentrated, with an ester linkage replacing the amide bond between the vanillyl moiety. The fatty acid chain is very similar to capsaicin. ${ }^{8}$

Ten studies investigating the ergogenic effects of capsaicinoids and capsinoids (CAP) supplementation have been published in the past 5 years. Our group recently investigated the effects of $12 \mathrm{mg}$ of capsiate ingestion during high-intensity interval exercise in physically active men, and observed an increase in time to 
exhaustion without a concomitant change in blood lactate concentration or oxygen consumption during exercise and postexercise. ${ }^{13}$ We also found that 12-mg capsiate ingestion increased the total volume performed during lower-body resistance exercise and decreased rating of perceived exertion (RPE). ${ }^{14}$ Taken together, this data indicates that capsiate could serve as a potential strategy to improve both endurance and strength performance. On the other hand, Opheim and Rankin ${ }^{11}$ reported that $25.8 \mathrm{mg}$ of CAP per day for 7 days in the form of a commercially available cayenne supplement did not enhance repeated-sprint performance in experienced athletes. Best et $\mathrm{al}^{15}$ recently reviewed a range of tastes including capsaicin/capsiate upon exercise performance and suggested that ingesting capsaicin as a capsule improved performance. To the best of our knowledge, there is no consensus regarding the effects of CAP on exercise performance. Therefore, the objective of this systematic review was to investigate the effects of CAP compounds as an ergogenic aid and to discuss the underlying mechanisms of action by which these supplements may potentially enhance endurance and resistance exercise performance.

\section{Methods}

The present systematic review was registered in an international database of prospectively registered systematic reviews in health and social care (PROSPERO, https://www.crd.york.ac.uk/prospero/) under registration number: CRD42018079825.

Two independent reviewers analyzed titles and abstracts and relevant full-text articles following specific inclusion criteria. Inclusion criteria for the present systematic review were (1) to use capsaicinoid (ie, capsaicin, dihydrocapsaicin) or capsinoids (ie, capsiate, dihydrocapsiate) compounds, (2) to include exercise, and (3) to investigate endurance or strength performances. The databases used in the search were as follows: PubMed, Science Direct, Scopus, Web of Science, SciELO, and LILACS.

The search strategy used consisted of a combination of databasespecific MeSH terms and Boolean operators ("AND" and "OR") following descriptors: Capsaicin OR capsaicinoid OR capsinoids OR capsiate AND Aerobic OR Endurance Exercise OR Endurance Training AND Performance AND Animal OR Human; Capsaicin OR capsaicinoid OR capsinoids OR capsiate AND Resistance Exercise OR Strength Exercise OR Resistance OR Strength Training AND Performance AND Animal OR Human. There was a restriction for English language but restrictions for publication period and systematic reviews were not included.

\section{Data Extraction}

Search results were exported to Excel software (Microsoft Corp, Redmond, WA), where duplicate articles were removed manually. First, 2 independent reviewers screened the exported studies to determine their relevance. Potentially relevant articles were retrieved as full-text articles and were evaluated against the eligibility criteria. If the 2 reviewers were uncertain or could not agree on the eligibility of studies, a third reviewer was invited to act as arbiter. The last examination of the literature was conducted in June 2019 and an update was performed in June 2020. After this process, 22 studies were included, as shown in Figure 1.

\section{Risk of Bias (Quality) Assessment}

Two independent reviewers assessed the quality of the studies and a third independent reviewer resolved any disagreement.
Methodological quality was not an inclusion criterion. The risk of bias tool covers 6 domains of bias: selection bias, performance bias, detection bias, attrition bias, reporting bias, and other bias, according to that proposed by the Cochrane Collaboration's tool for assessing the risk of bias in randomized trials. ${ }^{16}$ The second part of the tool involved assigning a judgment of high, low, or unclear risk of material bias for each item, and the quality of all studies analyzed is presented in Figure 2.

\section{Results}

There were 14 studies conducted with animals, of which 6 studies were acute and all demonstrated significant increases in swimming endurance capacity. There were only 2 studies that investigated the acute effect of capsiate on force. ${ }^{18,19}$ Faraut et $\mathrm{al}^{20}$ analyzed the acute effect of $100 \mathrm{mg} / \mathrm{kg}$ body weight on force production in gastrocnemius muscle in female rats and observed that capsiate administration did not affect the overall time course of isometric force both in the control $(39.5 \%)$ and capsiate groups $(35.1 \%)$. On the other hand, Kazuya et $\mathrm{al}^{19}$ compared 2 different doses of capsiate $(10 \mathrm{mg} / \mathrm{kg}$ vs $100 \mathrm{mg} / \mathrm{kg}$ ) on 6 minutes of maximal repeated isometric contractions and reported significant increases in total peak force $(22 \%)$ with the highest dose.

There were 6 studies comparing the chronic effect of CAP in animals, of which 3 studies investigated the effect on running distance but only Luo et $\mathrm{al}^{21}$ demonstrated increases in performance, where mice ran about $300 \mathrm{~m}$ more before than control after 3-month capsaicin treatment. In contrast, Dousset et $\mathrm{al}^{22}$ verified that neonatally capsaicin-treated rats had impaired performance (ie, $-35 \mathrm{~min}$ or $-12 \%$ of run), and Ohyama et $\mathrm{al}^{23}$ did not find benefits on running distance in mice treated with capsaicin analogs.

There were 3 chronic studies investigating the effect of resistance exercise in rats, but only Hsu et $\mathrm{al}^{24}$ showed a dose-dependent effect in the forelimb grip strength (control $=118 \mathrm{~g}, 205 \mathrm{mg} / \mathrm{kg} \mathrm{CAP}=$ $117 \mathrm{~g}, 410 \mathrm{mg} / \mathrm{kg} \mathrm{CAP}=125 \mathrm{~g}$, and $1025 \mathrm{mg} / \mathrm{kg} \mathrm{CAP}=131 \mathrm{~g}$ ) and time to exhaustion (control $=9.3 \mathrm{~min}, 205 \mathrm{mg} / \mathrm{kg} \mathrm{CAP}=11.06 \mathrm{~min}$, $410 \mathrm{mg} / \mathrm{kg} \mathrm{CAP}=11.28 \mathrm{~min}$, and $1025 \mathrm{mg} / \mathrm{kg} \mathrm{CAP}=46.99 \mathrm{~min}$ ), while Faraut et al ${ }^{18}$ verified isometric force production decreased throughout the stimulation period in control (69.1\% [4.0\%]) and capsiate groups $(71.6 \%$ [4.6\%]), but without significant difference between groups. Finally, Yashiro et $\mathrm{al}^{25}$ did not find significant differences between 10 and $100 \mathrm{mg} / \mathrm{kg}$ body weight of capsiate on force-generating capacity and fatigability after 2 weeks.

Table 1 summarizes the effects of CAP ingestion on endurance and strength performances in animals.

There were 5 studies that investigated the acute effect of CAP on running performance in humans. de Freitas et $\mathrm{al}^{14}$ reported significant increases in time to exhaustion during high-intensity intermittent exercise (15s:15s at $120 \%$ peak oxygen uptake $\left[\mathrm{VO}_{2}\right.$ peak]) with 12 -mg capsiate (102 efforts vs 89 efforts). The same authors also reported improvements in 1500-m running time trials $(\mathrm{CAP}=371.6$ [40.8] s vs placebo $=376.7$ [39] s $)$ and $\operatorname{RPE}(\mathrm{CAP}=18.0$ [1.9] vs placebo $=18.8[1.3])$ in physically active men with the same dose and supplement. ${ }^{31}$ Costa et $\mathrm{al}^{32}$ investigated the effect of $12-\mathrm{mg}$ capsiate on 400-m $(\mathrm{CAP}=66.4$ [4.2] s vs placebo $=67.1[4.8] \mathrm{s})$ and $3000-\mathrm{m}(\mathrm{CAP}=893.9$ [46.8] s vs placebo $=915.2$ [67.6] s $)$ running time trial and demonstrated significant improvements in both distances, but no differences for maximum heart rate (HR) and RPE were found. On the other hand, Padilha et $\mathrm{al}^{33}$ reported no improvements in time to exhaustion $(\mathrm{CAP}=654.3$ [195.4] vs placebo $=$ 709.2 [208.4] s), RPE, HR, lactate concentration, and oxygen consumption after high-intensity continuous exercise at $90 \% \mathrm{sVO}_{2}$ peak (the final incremental test speed at $\mathrm{VO}_{2}$ peak). In addition, 


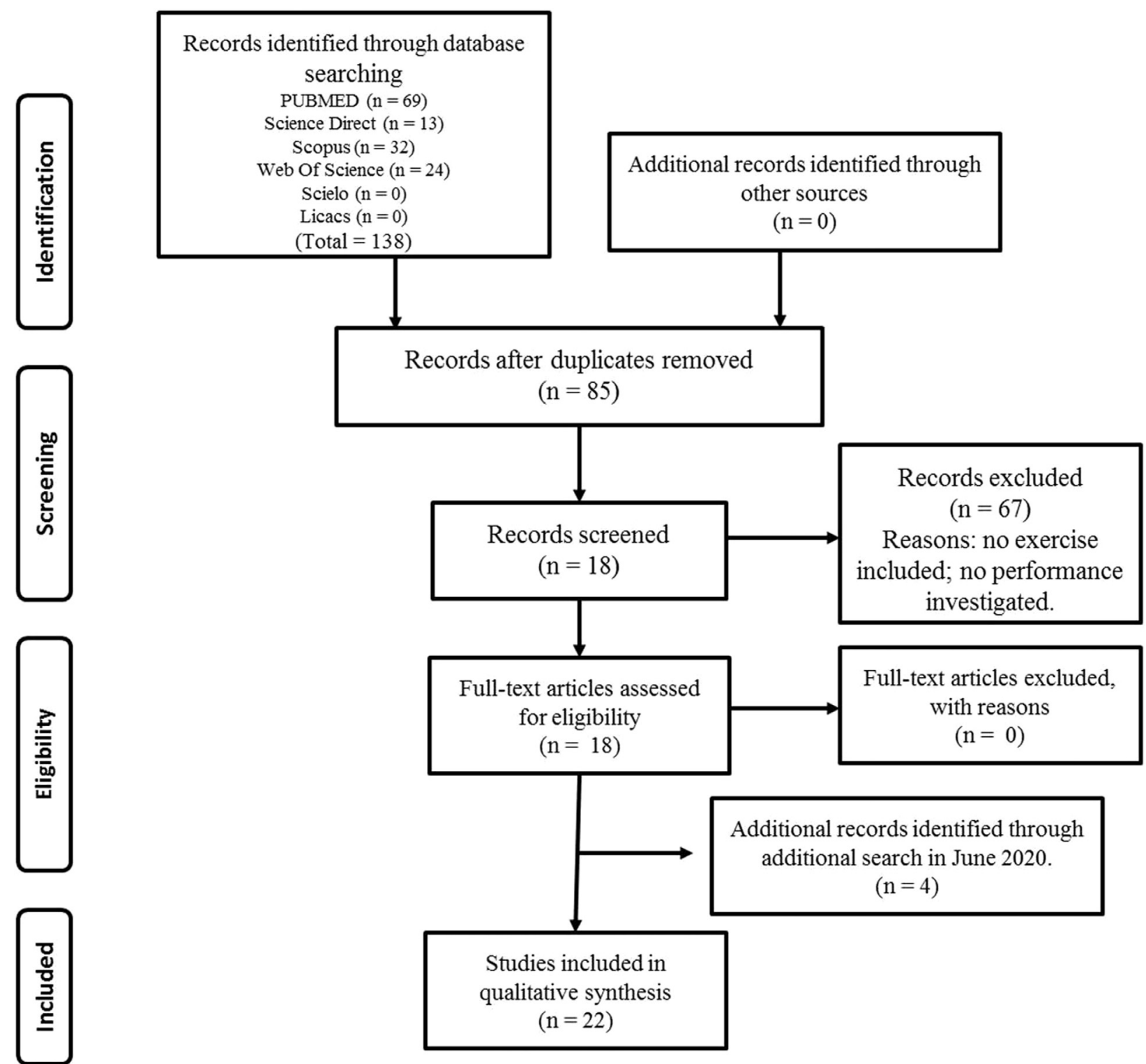

Figure 1 - Flow diagram.

Langan and Grosicki ${ }^{34}$ investigated if a chewable capsaicin supplement $(1.2 \mathrm{mg})$ could improve endurance cycling performance on a cycle ergometer at a workload eliciting $\sim 90 \% \mathrm{VO}_{2}$ max and did not find benefits for time to exhaustion $(\mathrm{CAP}=517.5$ [258.4] $\mathrm{s}$ vs placebo $=487.8[187.7] \mathrm{s}$ ) in active individuals.

There are only 2 acute studies investigating the effect of CAP on strength in humans. de Freitas et $\mathrm{al}^{14}$ compared $12 \mathrm{mg}$ of capsiate and placebo during 4 sets of back squats with $70 \%$ of 1RM and 90 -second rest between sets. The authors reported significant improvements in total repetitions performed $(\mathrm{CAP}=42.6[12.6]$ vs placebo $=\mathrm{PLA}=$ 35.1 [12.3] repetitions) and a decreased $\mathrm{RPE}(\mathrm{CAP}=17.2$ [1.0] vs placebo $=18.3[1.7])$. Cross et $\mathrm{al}^{10}$ verified the effect of chewable capsaicin supplement $(1.2 \mathrm{mg}$ ) on isokinetic knee extensor contractile performance in active individuals and demonstrated that knee extensor peak torque was significantly greater in the capsaicin (126.0 [40.4] N/m) than in the placebo (118.8 [41.3] N/m).

Regarding the chronic effect in humans, there was only one study in the literature. Opheim and Rankin ${ }^{11}$ investigated the effect of 6 treatment capsules with food per day for a total of $25.8 \mathrm{mg}$ of capsaicin (cayenne pepper) per day or placebo for 7 days on a repeated-sprint test consisting of $15 \times 30$-m sprints with 35 -second intervals. In this study, the authors did not find any significant improvements on performance.

Table 2 summarizes the effects of CAP ingestion on endurance and strength performances in humans.

\section{Discussion}

\section{Acute CAP Supplementation and Performance}

A total of 14 studies have investigated the effects of acute CAP supplementation on endurance performance in animals. For example, mice acutely supplemented with a nonpungent capsaicin analog $(0.02$ and $0.033 \mathrm{mmol} / \mathrm{kg})$ were able to swim longer before exhaustion than the control mice $(62.9$ vs $49.6 \mathrm{~min}, P<.05) .{ }^{27}$ The same authors later confirmed that the same dose of capsaicin increased the swimming endurance capacity, and also reported 
A

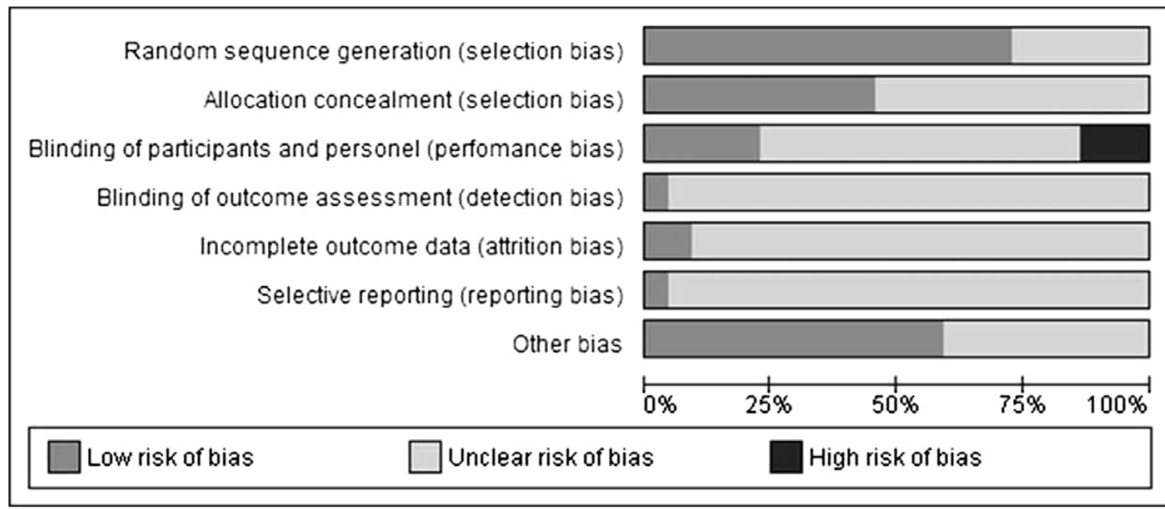

B

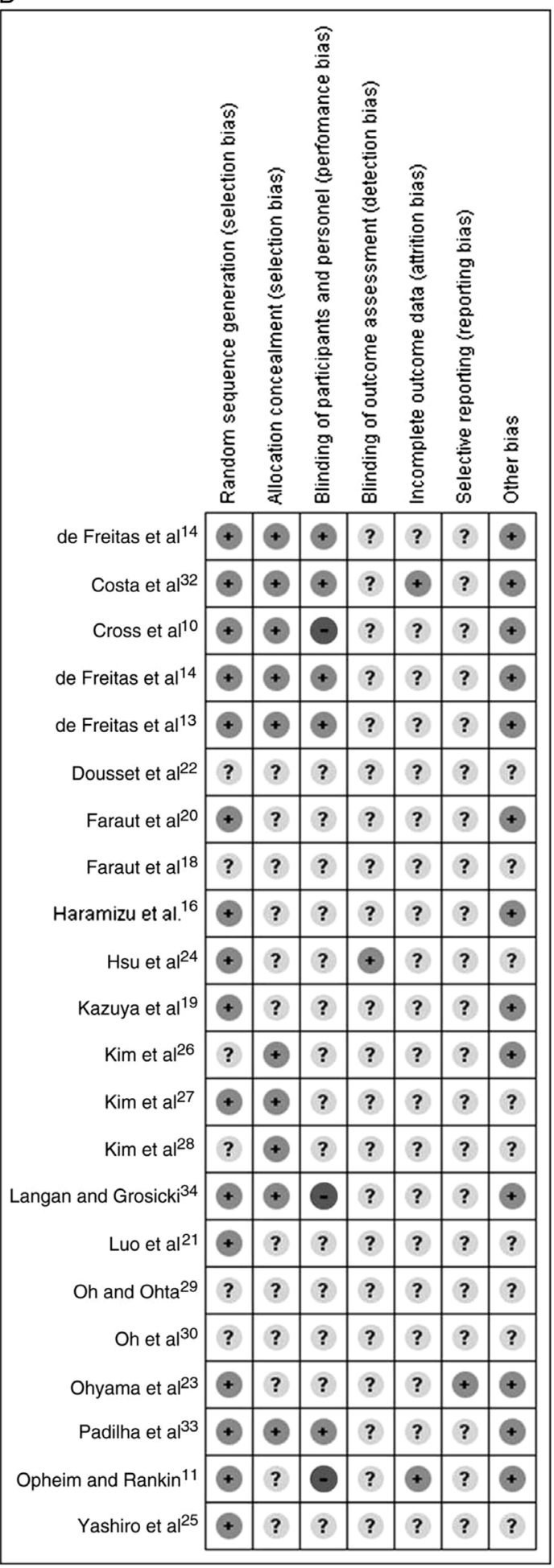

Figure 2 - (A) Risk-of-bias graph: the authors' judgments about each risk-of-bias item presented as percentages across all included studies. (B) Riskof-bias summary: the authors' judgments about each risk-of-bias item for each included study.

that co-supplementation of capsazepine (a capsaicin antagonist) with CAP reduced endurance capacity by suppressing the release of catecholamines. ${ }^{26,28}$ In accordance with these findings, $\mathrm{Oh}$ and Ohta ${ }^{29}$ demonstrated that supplementation of $15 \mathrm{mg} / \mathrm{kg}$ body weight of capsaicin 2 hours before exercise increased the swim time to exhaustion in rats, which was concomitant to increases in plasma concentrations of catecholamines, free fatty acids, and glucose. Interestingly, $\mathrm{Oh}$ et $\mathrm{al}^{30}$ also reported the effects of various doses of capsaicin on swim endurance capacity in rats. The highest dose (15 vs 6 and $10 \mathrm{mg} / \mathrm{kg}$ ) increased endurance performance time, plasma concentration of epinephrine, norepinephrine, free fatty acid, and spared tissue glycogen. These results tend to demonstrate that 
Table 1 Effect of CAP on Endurance and Strength Performances and Physiological Responses to Exercise in Animals

\begin{tabular}{|c|c|c|c|}
\hline Study & Sample & Exercise and supplement protocol & Results \\
\hline \multicolumn{4}{|c|}{$\begin{array}{l}\text { Acute supplementation- } \\
\text { endurance exercise }\end{array}$} \\
\hline Kim et $\mathrm{al}^{26}$ & $\begin{array}{l}\text { 6-wk-old male } \\
\text { mice }(n=6-8)\end{array}$ & $\begin{array}{l}\text { Capsaicin }(6 \mathrm{mg} / \mathrm{kg}) \text { was orally administered } 30 \mathrm{~min}, 1,2 \text {, or } 3 \mathrm{~h} \text { before } \\
\text { start of swimming. }\end{array}$ & $\begin{array}{l}\uparrow \text { swimming endurance } \\
\text { capacity }\end{array}$ \\
\hline Kim et $\mathrm{al}^{27}$ & $\begin{array}{l}\text { 6-wk-old mice } \\
(\mathrm{n}=21)\end{array}$ & $\begin{array}{l}\mathrm{C} 18-\mathrm{VA} \text { (Capsiate) } 0.033 \mathrm{mmol} / \mathrm{kg} \text { and placebo. Measurement of } \\
\text { swimming time was evaluated } 2 \mathrm{~h} \text { after. }\end{array}$ & $\begin{array}{l}\uparrow \text { swimming endurance } \\
\text { capacity }\end{array}$ \\
\hline Kim et $\mathrm{al}^{28}$ & $\begin{array}{l}\text { 6-wk-old male } \\
\text { mice }(n=6-8)\end{array}$ & $\begin{array}{l}\text { Capsaicin } 0.033 \mathrm{mmol} / \mathrm{kg} \text {, antagonist CAP }(0.17 \mathrm{mmol} / \mathrm{kg}) \text {, and } \\
\text { placebo. }\end{array}$ & $\begin{array}{l}\uparrow \text { swimming endurance } \\
\text { capacity }\end{array}$ \\
\hline Oh and $\mathrm{Ohta}^{29}$ & $\begin{array}{l}\text { 4-wk-old male } \\
\text { mice }(n=49)\end{array}$ & $\begin{array}{l}\text { Vehicle or a dose of capsaicin, } 6,10 \text {, or } 15 \mathrm{mg} / \mathrm{kg} \text { of body weight, } 2 \mathrm{~h} \\
\text { before exercise. }\end{array}$ & $\begin{array}{l}\uparrow \text { swimming time to } \\
\text { exhaustion in the } \\
\text { highest dose }\end{array}$ \\
\hline Oh et $\mathrm{al}^{30}$ & $\begin{array}{l}\text { 4-wk-old male } \\
\text { mice }(n=49)\end{array}$ & $\begin{array}{l}\text { Rats were given orally either control }(0) \text { or } 6,10 \text {, or } 15 \mathrm{mg} \text { capsaicin } / \mathrm{kg} \\
\text { body weight } 2 \mathrm{~h} \text { before exercise by stomach intubations using a } \\
\text { round-ended needle. }\end{array}$ & $\begin{array}{l}\uparrow \text { swimming time to } \\
\text { exhaustion in the } \\
\text { highest dose }\end{array}$ \\
\hline Haramizu et al $^{16}$ & $\begin{array}{l}\text { Male mice } \\
(\mathrm{n}=7)\end{array}$ & $\begin{array}{l}\text { Mice orally given capsiate }(10 \mathrm{mg} / \mathrm{kg}) \text { and swam } 30 \mathrm{~min} \text { at a flow rate } \\
\text { of } 7 \mathrm{~L} / \mathrm{min} \text {. }\end{array}$ & 个endurance swimming \\
\hline \multicolumn{4}{|c|}{$\begin{array}{l}\text { Prolonged supplementation- } \\
\text { endurance exercise }\end{array}$} \\
\hline Dousset et $\mathrm{al}^{22}$ & $\begin{array}{l}\text { Neonatal female } \\
\text { rats }(n=34)\end{array}$ & $\begin{array}{l}\text { Rats were subcutaneously injected on the second day of life with } \\
\text { capsaicin at a dose of } 50 \mathrm{mg} / \mathrm{kg} \text {. Three months after birth, they } \\
\text { performed one exhaustive forced run on a treadmill. }\end{array}$ & $\leftrightarrow$ performance \\
\hline Luo et $\mathrm{al}^{21}$ & $\begin{array}{l}\text { Male mice } \\
\text { (aged 6-8 wk) }\end{array}$ & $\begin{array}{l}\text { Animals were fed with this diet supplemented with } 0.01 \% \text { capsaicin } \\
\text { diets for } 12 \text { mo. }\end{array}$ & $\uparrow$ running distance \\
\hline Ohyama et $\mathrm{al}^{23}$ & $\begin{array}{l}\text { 7-wk-old male } \\
\text { mice }\end{array}$ & $\begin{array}{l}\text { (1) HFD, (2) HFD with } 0.3 \% \text { capsinoids, (3) HFD with voluntary } \\
\text { running wheel exercise, and (4) HFD containing } 0.3 \% \text { capsinoids with } \\
\text { voluntary running wheel exercise. Running distance was monitored } \\
\text { twice a week for } 8 \text { wk. }\end{array}$ & $\leftrightarrow$ performance \\
\hline \multicolumn{4}{|c|}{$\begin{array}{l}\text { Acute supplementation- } \\
\text { resistance exercise }\end{array}$} \\
\hline Faraut et $\mathrm{al}^{20}$ & $\begin{array}{l}\text { Female rats } \\
(\mathrm{n}=38)\end{array}$ & $\begin{array}{l}\text { Vehicle or } 100 \mathrm{mg} / \mathrm{kg} \text { body weight capsiate, and measurements were } \\
\text { performed } 2 \mathrm{~h} \text { after the treatment. }\end{array}$ & $\leftrightarrow$ force \\
\hline Kazuya et al $^{19}$ & Mice $(n=22)$ & $\begin{array}{l}\text { Vehicle, capsiate at } 10 \mathrm{mg} / \mathrm{kg} \text {, or capsiate at } 100 \mathrm{mg} / \mathrm{kg} \text {. Two hours after } \\
\text { intake, they performed } 6 \mathrm{~min} \text { of maximal repeated isometric } \\
\text { contractions. }\end{array}$ & $\begin{array}{l}\uparrow \text { twitch force- } \\
\text { generating capacity in } \\
\text { the highest dose }\end{array}$ \\
\hline \multicolumn{4}{|c|}{$\begin{array}{l}\text { Prolonged supplementation- } \\
\text { resistance exercise }\end{array}$} \\
\hline Faraut et al ${ }^{18}$ & $\begin{array}{l}\text { Female rats } \\
(\mathrm{n}=24)\end{array}$ & $\begin{array}{l}\text { Capsiate }(100 \mathrm{mg} / \mathrm{kg}) \text { for } 14 \text { consecutive days. Force measurement } \\
\text { protocol consisted in electrical stimulations on the gastrocnemius muscle. }\end{array}$ & $\leftrightarrow$ force \\
\hline Yashiro et $\mathrm{al}^{25}$ & $\begin{array}{l}\text { 12-wk-old male } \\
\text { mice }(n=41)\end{array}$ & Capsiate $(10$ or $100 \mathrm{mg})$ for 14 consecutive days. & $\leftrightarrow$ force \\
\hline Hsu et $\mathrm{al}^{24}$ & $\begin{array}{l}8 \text {-wk-old female } \\
\text { mice }(n=32)\end{array}$ & $\begin{array}{l}\text { (1) Vehicle control, (2) } 205 \mathrm{mg} / \mathrm{kg} \text { capsaicin, (3) } 410 \mathrm{mg} / \mathrm{kg} \text { capsaicin, } \\
\text { and (4) } 1025 \mathrm{mg} / \mathrm{kg} \text { CAP once a day for } 28 \text { consecutive days. }\end{array}$ & $\begin{array}{l}\uparrow \text { grip strength and } \\
\text { swimming time were } \\
\text { greater in the higher } \\
\text { dose }\end{array}$ \\
\hline
\end{tabular}

Abbreviations: CAP, capsaicinoids and capsinoids; HFD, high-fat diet. Note: $\uparrow$, significantly increased; $\downarrow$, significantly decreased; $\leftrightarrow$, not changed.

the more capsaicin ingested (at least up to $15 \mathrm{mg} / \mathrm{kg}$ ), the greater the effects on performance in animals.

We were able to find only 5 studies in humans. de Freitas et $\mathrm{al}^{31}$ analyzed the effects of capsiate supplementation on performance, RPE, and blood lactate concentration during middle-distance running in physically active adults. Capsiate supplementation significantly improved 1500-m run performance and reduced RPE more than a placebo supplement. Similarly, de Freitas et $\mathrm{al}^{13}$ investigated the acute effect of capsiate supplementation on performance and physiological responses during high-intensity intermittent exercise. Thirteen physically active men performed 2 randomized, double-blind high-intensity intermittent exercise (15s: $15 \mathrm{~s}$ at $120 \%$ speed at $\mathrm{VO}_{2}$ peak) trials 45 minutes after consuming $12 \mathrm{mg}$ of capsiate or a placebo. The results showed that capsiate increased the time to exhaustion by 188 seconds (13 efforts more than in placebo, which represents a $13 \%$ improvement in performance), without modifying RPE and metabolic responses such as blood lactate and oxygen consumption during exercise and postexercise (fast phase of oxygen consumption and 20-min postexercise). Recently, Costa et $\mathrm{al}^{32}$ investigated the effect of capsiate supplementation on short- $(400 \mathrm{~m})$ and middle-distance $(3000 \mathrm{~m})$ running timetrial performance, RPE, and HR in physically active men, and observed a decrease in both time trials but no change in RPE and HR. 
Table 2 Effects of Capsaicin Ingestion on Endurance and Strength Performance in Humans

\begin{tabular}{|c|c|c|c|}
\hline Study & Sample & Exercise and supplement protocol & Results \\
\hline \multicolumn{4}{|l|}{$\begin{array}{l}\text { Acute supplementation- } \\
\text { endurance exercise }\end{array}$} \\
\hline de Freitas et $\mathrm{al}^{14}$ & $\begin{array}{l}\text { Physically active } \\
\text { men }(n=10)\end{array}$ & $\begin{array}{l}\text { Capsaicin }(12 \mathrm{mg}) \text { or placebo. The participants performed a } 1500-\mathrm{m} \\
\text { running time trial, } 45 \mathrm{~min} \text { after supplement consumption. }\end{array}$ & $\begin{array}{l}\downarrow \text { time to run } 1500 \mathrm{~m} \\
\downarrow \mathrm{RPE}\end{array}$ \\
\hline de Freitas et $a^{13}$ & $\begin{array}{l}\text { Physically active } \\
\text { men }(\mathrm{n}=13)\end{array}$ & $\begin{array}{l}\left.\text { HIIT (15:15 s at } 120 \% \text { speed at } \mathrm{VO}_{2} \text { peak }\right) \text { trials } 45 \mathrm{~min} \text { after } \\
\text { consuming capsaicin }(12 \mathrm{mg}) \text { or placebo. }\end{array}$ & $\begin{array}{l}\uparrow \text { time to exhaustion; } \\
\leftrightarrow \text { RPE. }\end{array}$ \\
\hline Costa et $\mathrm{al}^{32}$ & $\begin{array}{l}\text { Physically active } \\
\text { men }(\mathrm{n}=12)\end{array}$ & $\begin{array}{l}\text { Two randomized, double-blind trials: capsaicin }(12 \mathrm{mg} \text { ) or placebo. } \\
\text { The participants performed a } 400-\text { and } 3000-\mathrm{m} \text { running time trial, } \\
45 \text { min after supplement consumption. Time (in seconds), HR, and } \\
\text { the RPE were assessed. }\end{array}$ & $\begin{array}{l}\downarrow \text { time to run } 400 \text { and } \\
3000 \mathrm{~m} \\
\leftrightarrow \mathrm{HR} \\
\leftrightarrow \mathrm{RPE}\end{array}$ \\
\hline Padilha et $\mathrm{al}^{33}$ & $\begin{array}{l}\text { Recreationally } \\
\text { trained runners } \\
(\mathrm{n}=16)\end{array}$ & $\begin{array}{l}\text { The subjects completed } 2 \text { randomized, double-blind conditions. } \\
\text { They performed high-intensity continuous exercise at } 90 \% \mathrm{sVO}_{2-} \\
\text { peak, } 45 \mathrm{~min} \text { after consuming capsaicin }(12 \mathrm{mg}) \text { or an isocaloric } \\
\text { placebo. The time to exhaustion was evaluated. }\end{array}$ & $\begin{array}{l}\leftrightarrow \text { not effect on time to } \\
\text { exhaustion }\end{array}$ \\
\hline Langan and Grosicki ${ }^{34}$ & $\begin{array}{l}\text { Recreationally } \\
\text { active men and } \\
\text { woman }(n=13)\end{array}$ & $\begin{array}{l}\text { Participants performed a protocol of } 90 \% \text { of } \mathrm{VO}_{2} \text { max individual } \\
\text { during cycling after } 45 \mathrm{~min} \text { of ingesting } 1.2 \mathrm{mg} \text { capsaicin fruit } \\
\text { gummy or eucaloric placebo. }\end{array}$ & $\begin{array}{l}\leftrightarrow \text { not effect on time to } \\
\text { exhaustion }\end{array}$ \\
\hline \multicolumn{4}{|l|}{$\begin{array}{l}\text { Acute supplementation- } \\
\text { resistance exercise }\end{array}$} \\
\hline de Freitas et $\mathrm{al}^{14}$ & $\begin{array}{l}\text { Men trained in } \\
\text { resistance }(n=10)\end{array}$ & $\begin{array}{l}\text { Capsaicin condition }(12 \mathrm{mg}) \text { or placebo. Participants performed } 4 \text { sets, } \\
\text { up to failure, of movement in the squatting exercise at } 70 \% \text { of } 1 \mathrm{RM} \\
\text { with } 90 \text {-s rest interval between sets, } 45 \text { min after supplement intake. }\end{array}$ & $\begin{array}{l}\uparrow \text { number of repetition; } \\
\downarrow \mathrm{RPE}\end{array}$ \\
\hline Cross et $\mathrm{al}^{10}$ & $\begin{array}{l}\text { Recreationally } \\
\text { active men and } \\
\text { woman }(n=9)\end{array}$ & $\begin{array}{l}\text { Participants completed } 2 \text { isokinetic knee extensor contractile } \\
\text { function assessments, } 45 \text { min after ingesting either a capsaicin fruit } \\
\text { gummy or eucaloric placebo. }\end{array}$ & $\begin{array}{l}\uparrow \text { knee extensor peak } \\
\text { torque }\end{array}$ \\
\hline \multicolumn{4}{|l|}{$\begin{array}{l}\text { Prolonged supplementation- } \\
\text { endurance exercise }\end{array}$} \\
\hline Opheim and Rankin ${ }^{11}$ & $\begin{array}{l}\text { Men participating } \\
\text { in a sport }(n=19)\end{array}$ & $\begin{array}{l}\text { The subjects consumed } 6 \text { treatment capsules with food per day for a } \\
\text { total of } 25.8 \mathrm{mg} \text { of capsaicin per day or placebo for } 7 \mathrm{~d} \text {. Repeated- } \\
\text { sprint test consisted of } 15 \times 30 \text {-m sprints on } 35 \text {-s intervals. }\end{array}$ & $\leftrightarrow$ performance \\
\hline
\end{tabular}

Abbreviations: 1RM, 1-repetition maximum; HIIT, high-intensity interval training; HR, heart rate; RPE, rating of perceived exertion. Note: $\uparrow$, significantly increased; $\downarrow$, significantly decreased; $\leftrightarrow$, not changed.

Padilha et $\mathrm{al}^{33}$ investigated the effect of acute capsiate supplementation $(12 \mathrm{mg})$ on time to exhaustion, physiological responses, and energetic systems contribution during continuous high-intensity exercise session in runners. The subjects completed 2 randomized, double-blind continuous high-intensity exercises at $90 \% \mathrm{sVO}_{2}$ peak, 45 minutes after consuming capsiate or an isocaloric placebo. Time to exhaustion, blood lactate concentration, oxygen consumption during exercise and 20-minute postexercise, energy systems contribution, time to reach $\mathrm{VO}_{2}$ peak, $\mathrm{HR}$, and $\mathrm{RPE}$ were evaluated. Acute capsiate supplementation did not increase the time to exhaustion during high-intensity continuous exercise nor alter physiological responses in runners. Langan and Grosicki ${ }^{34}$ assessed the acute effect of chewable capsaicin supplement $(1.2 \mathrm{mg}) 45$ minutes before a test until cycling exhaustion at $\sim 90 \%$ individual $\mathrm{VO}_{2}$ max in active men and women. Capsaicin did not increase performance compared with ingested placebo, with no differences in HR, pedaling cadence, and RPE. Taken together, these studies suggest that acute capsaicin supplementation may improve endurance performance in humans, but this ergogenic effect depends upon the protocol and maybe the type of CAP used.

Studies investigating the acute effects of CAP on performances during resistance exercise are scarce. Kazuya et al ${ }^{19}$ analyzed the effects of a single intake of a low $(10 \mathrm{mg} / \mathrm{kg})$ and high $(100 \mathrm{mg} / \mathrm{kg})$ dose of capsiate on gastrocnemius muscle performance and energetics in mice. The results showed that a higher dose increased force-generating capabilities in skeletal muscle and reduced the ATP cost for 6 minutes of repeated fatiguing isometric contractions.

To our best knowledge, only 2 studies investigated the effects of capsiate on resistance exercise performance in humans. de Freitas et $\mathrm{al}^{14}$ investigated the effects of $12-\mathrm{mg}$ capsiate supplementation on resistance exercise performance (4 sets to muscular failure with $70 \%$ of $1 \mathrm{RM}$ in squat exercise) in trained men. Capsiate significantly increased total weight lifted (capsaicin: 3919.4 vs placebo: $3179.6 \mathrm{~kg}$ ) while reducing RPE, but did not significantly alter the blood lactate concentration. Cross ${ }^{10}$ also verified the acute effect of chewable capsaicin supplementation $(1.2 \mathrm{mg})$ on the isokinetic knee extensors in physically active men and women. Peak torque production was higher after capsaicin supplementation with no difference in the sum of torque or fatigue index. Although these preliminary data are very relevant to fitness conditioning, future research is certainly warranted to determine the efficacy of chronic capsaicin supplementation in various populations.

\section{Chronic CAP Supplementation and Performance}

Despite several studies investigating the acute effects of CAP on performance with relatively beneficial results, there is a lack of chronic studies in the research literature, particularly in humans. In mice, Luo et $\mathrm{al}^{21}$ demonstrated that running distance on a treadmill increased over the course of 12 months when a high-fat diet was supplemented with $0.01 \%$ of capsaicin compared with animals 
maintaining a normal diet. On the contrary, Ohyama et $\mathrm{al}^{23}$ showed that capsinoid supplementation associated with a high-fat diet did not increase running performance in rats; however, the authors reported increased energy expenditure with capsinoid supplementation via the activation of fat oxidation in skeletal muscle and lipolysis in brown adipose tissue. There is more data available in the literature about the combination of CAP with resistance training. For example, Hsu et $\mathrm{al}^{24}$ reported that 4 weeks of capsaicin supplementation increased relative forelimb grip strength in a dose-dependent manner, with the greatest values observed in the group of mice receiving $1025 \mathrm{mg}$ capsaicin $/ \mathrm{kg} /$ $\mathrm{d}$ (approximately 5-fold the usual human equivalent dose). On the other hand, with a much lower dose $(100 \mathrm{mg} / \mathrm{kg})$, Faraut et al ${ }^{18}$ did not show any change in isometric force in the gastrocnemius muscle of rats after 14 days of capsiate supplementation.

In humans, Opheim and Rankin ${ }^{12}$ demonstrated that supplementation of $25.8 \mathrm{mg}$ of capsaicin (cayenne pepper) per day over 7 days did not improve repeated-sprint performance $(15 \times 30-\mathrm{m}$ sprints with 35-s intervals) in experienced athletes. However, with such a large dose in the form of cayenne pepper, the authors reported gastrointestinal discomfort in $25 \%$ of the participants. Thus, it is possible that such level of discomfort affected the physical capacity of the participants and, thereby, limited the interpretations derived from Opheim and Rankin ${ }^{11}$ study.

On the other hand, Cross et $\mathrm{al}^{10}$ found an improvement in isokinetic knee extensor torque, but not muscular endurance or fatigue, with a chewable, low-dose $(1.2 \mathrm{mg})$ capsaicin supplement. It is unclear whether buccal absorption of capsaicin may have occurred or whether the pungent sensation of oral heat induced a stimulation of targeted receptors in the oral cavity. ${ }^{15}$ Future studies are necessary to investigate the Pharmacokinetics and ergogenic response to different oral delivery methods.

\section{Potential Mechanisms Underlying CAP Ergogenicity}

The potential mechanism that may explain the ergogenic effects of CAP on performance has been through modulation of the transient receptor potential vanilloid 1 (TRPV1) channel, as illustrated in Figure 3. ${ }^{35}$ Mechanisms related to TRPV1 agonists include the following: (1) increase in calcium release in the sarcoplasmic reticulum of muscle cells resulting in reduced muscular fatigue, ${ }^{36}$ (2) increase in fatty acid oxidation thereby providing more available energy and improved body composition, ${ }^{18,29,37}$ (3) having an analgesic effect and increasing pain tolerance during exercise, ${ }^{35,38,39}$ (4) glycogen sparing properties attenuating declines in force production, ${ }^{19,24,29}$ and (5) increase in the release of acetylcholine resulting in increased explosive power and increased endurance performance. ${ }^{21,28}$

Skeletal muscle peripheral fatigue is a limiting factor in forcegenerating capacity, ${ }^{40}$ and lower calcium release by the sarcoplasmic reticulum results in an impairment in contractile efficiency and myofiber force production. ${ }^{41,42}$ In the skeletal muscle, TRPV1 are located in close proximity to the sarcoplasmic reticulum whereby activation by CAP increases the release of calcium, ${ }^{36,43,44}$ which may improve the interaction between the actin-myosin filaments. ${ }^{19,45}$ The TRPV1 are also present at the neuromuscular junction, whereby stimulation by CAP can induce presynaptic modulation at the neuromuscular junction leading to an increase in evoked acetylcholine release. ${ }^{35,46}$

Luo et $\mathrm{al}^{21}$ examined the influence of capsaicin on TRPV1 activation and calcium release in skeletal muscle of rats. Acute supplementation of capsaicin elevated the amounts of calcium in myotubes; however, when TRPV1 was blocked by 5'-iodo- resiniferatoxin (antagonist of TRPV1), the release of calcium was inhibited. Lotteau et $\mathrm{al}^{36}$ further showed that capsaicin and resiniferatoxin, both agonists of TRPV1, elicit an increase in calcium in mouse muscle fibers. In addition, the inhibition of TRPV1 by capsazepine resulted in a strong inhibition of the calcium release by the sarcoplasmic reticulum. Based on Luo et $\mathrm{al}^{21}$ and Lotteau et $\mathrm{al}^{36}$ studies, it is likely that capsaicin increases performance by activating the TRPV1 receptor in skeletal muscle, improving sarcoplasmic reticulum function and muscular force output. That being said, future studies will need to test this hypothesis in humans.

The reduction of skeletal muscle glycogen content has also been proposed as one important potential mechanism of peripheral locomotor muscle fatigue. ${ }^{47}$ There is a close association between low glycogen stores and impaired calcium release by the sarcoplasmic reticulum, suggesting that when muscle glycogen is lower, the efficiency of skeletal muscle to produce force is decreased. ${ }^{47} \mathrm{In}$ this perspective, delaying the reduction of muscle glycogen via carbohydrate ingestion has been shown to increase performance during endurance exercise. ${ }^{48}$

Animal studies have suggested that CAP supplementation increases swimming time to exhaustion (see Table 2), and performance gains were explained in part by an increase in plasma free fatty acid availability as a result of higher epinephrine release, leading a glycogen sparing effect. ${ }^{27,29}$ The hypothesis is that capsaicin may increase lipolysis in adipose tissue, raise free fatty acid levels, and increase fatty acid uptake by skeletal muscle, and glucose release from hepatic glycogenolysis and gluconeogenesis. Yashiro et $\mathrm{al}^{25}$ demonstrated that 2 weeks of capsiate resulted in a reduced oxidative cost of contraction in exercising mouse skeletal muscle. The CAP ingestion also upregulates genes involved in fatty acid oxidation and mitochondrial respiration. ${ }^{21}$ Theoretically, this would lead to a higher contribution of beta-oxidation toward the resynthesis of ATP, thereby decreasing the dependence on muscle glycogen to generate energy during exercise. These results provide a mechanistic rationale whereby CAP may improve muscular and aerobic endurance providing shifting substrate utilization. ${ }^{37,49}$

The analgesic effect induced by CAP is another potential mechanism that may explain its ergogenic effects. Topical CAP has been used as a pain reliever in neuropathic conditions, ${ }^{38,39}$ and sufficient doses of CAP that activate the TRPV1 receptor have been shown to possess analgesic effects by inactivating or desensitizing primary afferent nerve endings as a result of calcium overload. Studies have demonstrated that capsaicin may affect the RPE during exercise. For example, de Freitas et $\mathrm{al}^{14}$ reported a lower RPE after consuming capsiate during 4 sets of squat exercise performed until muscular failure at $70 \% 1 \mathrm{RM}$ in trained men and during short-duration running in physically active adults. ${ }^{31}$ It is possible that CAP supplementation may have increased the pain threshold and reduced discomfort induced by fatiguing exercise, thereby resulting in performance gains.

\section{Practical Applications and Future Perspectives}

Although CAP, a natural substance found in chili peppers and other spicy foods, presents promising ergogenic potential, the ergogenic effect of CAP on human exercise performance is currently equivocal, and significant scientific work is needed to demonstrate a consistent mechanism of action. Therefore, future research should investigate the effects of CAP in association with chronic resistance training, aerobic exercise, and concurrent exercise in humans. Research should also ascertain the mechanisms proposed in the present review, 


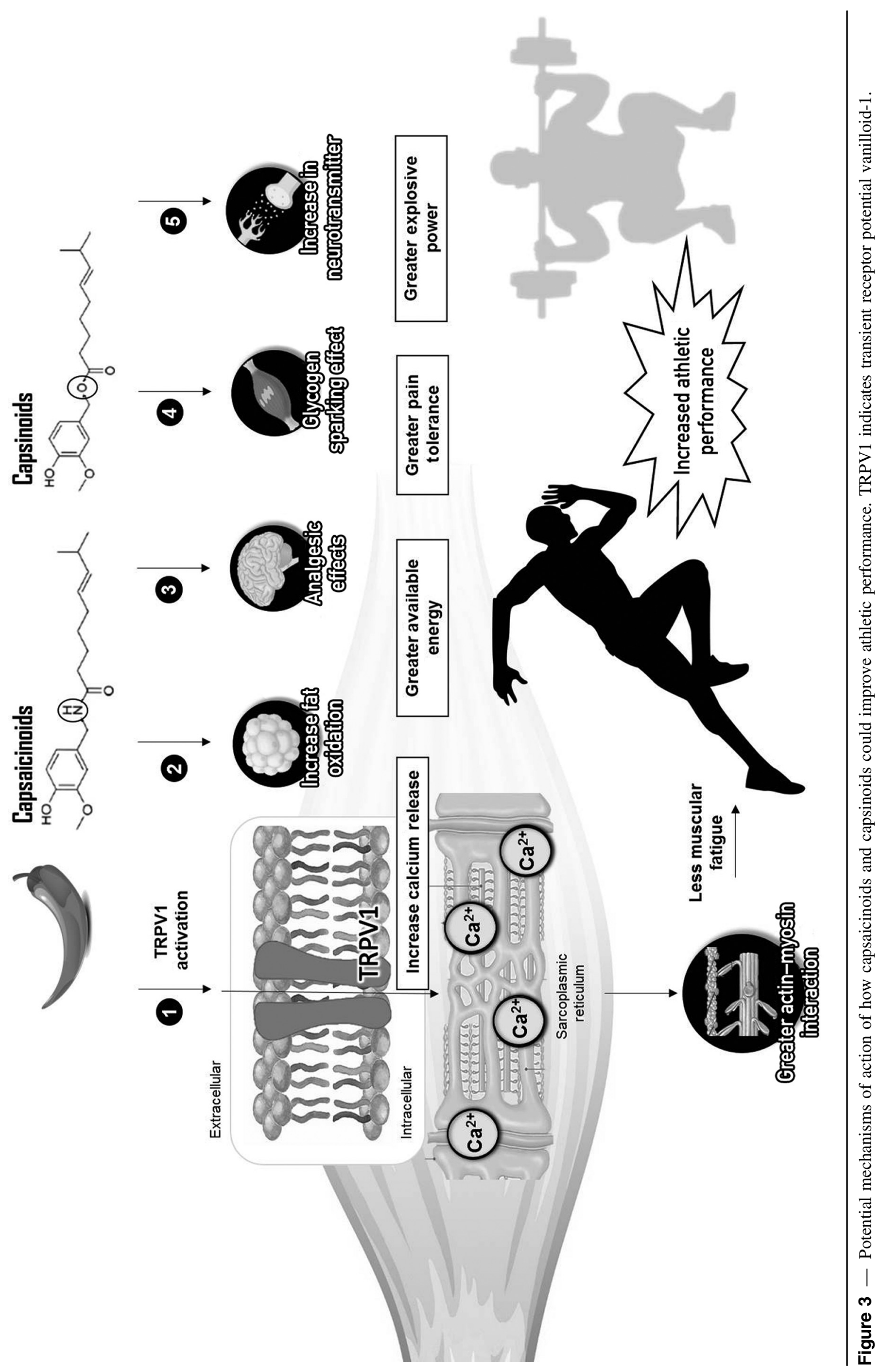


in particular, the hypothesis that CAP may increase the lipolysis and fatty acid oxidation, thereby decreasing the dependence on intramuscular glycogen stores to generate energy during exercise. The greater calcium release by the sarcoplasmic reticulum and the analgesic effect, which would increase the pain threshold and reduce discomfort induced by fatiguing exercise, should also be examined in humans. And since these physiological mechanisms (especially, substrate partitioning and pain threshold) may be different in men and women, ${ }^{50,51}$ more research should include female participants in their trials to ascertain and understand the efficacy of CAP in women. In addition, since most studies to date have been focused on fat loss and energy intake, ${ }^{52,53}$ CAP could be a potential tool for athletes competing in weight classes or in sports where reduced body weight is beneficial; however, further studies are necessary to verify this hypothesis and to measure the muscular hypertrophy outcomes. It is necessary to highlight that difference between exercise protocols used in the literature, different doses and types of supplementation strategy (capsaicinoid [capsaicin] and capsinoids [capsiate]), and levels of physical fitness (untrained vs trained) should be considered when interpreting the results between studies.

\section{Conclusion}

In summary, among 22 studies included in the present systematic review, 14 examined the effects of capsaicinoid or capsinoid compounds on endurance and resistance exercise performance in animals with 9 studies showing benefits on performance. In humans, 8 studies were included, of which 3 demonstrated significant acute endurance benefits and 2 acute resistance exercise performance benefits. Therefore, while more mechanistic studies are necessary to confirm these outcomes in humans, the available scientific literature appears to suggest that these compounds could be considered as potential new nutritional strategy to improve exercise performance.

\section{Acknowledgments}

We thank Dr Ralf Jäger and Increnovo LCC for paying the fee to publish this Systematic Review as open access.

\section{References}

1. Thomas DT, Erdman KA, Burke LM. American College of Sports Medicine Joint Position Statement. Nutrition and athletic performance. Med Sci Sports Exerc. 2016;48(3):543-568. PubMed ID: 26891166 doi:10.1249/MSS.0000000000000852

2. Cholewa J, Trexler E, Lima-Soares F, et al. Effects of dietary sports supplements on metabolite accumulation, vasodilation and cellular swelling in relation to muscle hypertrophy: a focus on "secondary" physiological determinants. Nutrition. 2019;60:241-251. PubMed ID: 30682546 doi:10.1016/j.nut.2018.10.011

3. Li F, Lin Y, Wang X, Geng Y, Wang D. Preparative isolation and purification of capsaicinoids from Capsicum frutescens using highspeed counter-current chromatography. Sep Purif Technol. 2009; 64(3):304-308. doi:10.1016/j.seppur.2008.10.005

4. Sganzerla M, Coutinho JP, de Melo AMT, Godoy HT. Fast method for capsaicinoids analysis from Capsicum chinense fruits. Food Res Int. 2014;64:718-725. PubMed ID: 30011708 doi:10.1016/j.foodres. 2014.08.003

5. O’Neil CK, Hanlon JT, Marcum ZA. Adverse effects of analgesics commonly used by older adults with osteoarthritis: focus on nonopioid and opioid analgesics. Am J Geriatr Pharmacother. 2012; 10(6):331-342. PubMed ID: 23036838
6. Suresh D, Srinivasan K. Tissue distribution \& elimination of capsaicin, piperine \& curcumin following oral intake in rats. Indian $J$ Med Res. 2010;131(5):682-691.

7. Chaiyasit K, Khovidhunkit W, Wittayalertpanya S. Pharmacokinetic and the effect of capsaicin in Capsicum frutescens on decreasing plasma glucose level. J Med Assoc Thai. 2009;92(1):108-113. PubMed ID: 19260251

8. Bernard BK, Tsubuku S, Kayahara T, et al. Studies of the toxicological potential of capsinoids: X. Safety assessment and pharmacokinetics of capsinoids in healthy male volunteers after a single oral ingestion of CH-19 Sweet extract. Int J Toxicol. 2008;27(3 suppl): 137-147. doi:10.1080/10915810802514476

9. Sharma SK, Vij AS, Sharma M. Mechanisms and clinical uses of capsaicin. Eur J Pharmacol. 2013;720(1-3):55-62. PubMed ID: 24211679 doi:10.1016/j.ejphar.2013.10.053

10. Cross BL, Parker D, Langan SP, Grosicki GJ. Effect of a commercially available low-dose capsaicin supplement on knee extensor contractile function. Int J Exerc Sci. 2020;13(2):312-318. PubMed ID: 32148619

11. Opheim MN, Rankin JW. Effect of capsaicin supplementation on repeated sprinting performance. J Strength Cond Res. 2012;26(2): 319-326. PubMed ID: 22130402 doi:10.1519/JSC.0b013e3182429ae5

12. Batiha GE, Alqahtani A. Biological properties, bioactive constituents, and pharmacokinetics of some Capsicum spp. and capsaicinoids. Int J Mol Sci. 2020;21(15):5179. doi:10.3390/ijms21155179

13. de Freitas MC, Billaut F, Panissa VLG, et al. Capsaicin supplementation increases time to exhaustion in high-intensity intermittent exercise without modifying metabolic responses in physically active men. Eur J Appl Physiol. 2019;119(4):971-979. doi:10.1007/s00421-019-04086-w

14. de Freitas MC, Cholewa JM, Freire RV, et al. Acute capsaicin supplementation improves resistance training performance in trained men. Eur J Appl Physiol. 2018;32(8):2227-2232. doi:10.1519/jsc. 0000000000002109

15. Best R, McDonald K, Hurst P, Pickering C. Can taste be ergogenic? [published online ahead of print May 16, 2020]. Eur J Nutr. doi:10. 1007/s00394-020-02274-5

16. Haramizu S, Mizunoya W, Masuda Y, et al. Capsiate, a nonpungent capsaicin analog, increases endurance swimming capacity of mice by stimulation of vanilloid receptors. Biosci Biotechnol Biochem. 2006;70(4):774-781. doi:10.1271/bbb.70.774

17. Higgins JP, Altman DG, Gøtzsche PC, et al. The Cochrane Collaboration's tool for assessing risk of bias in randomised trials. BMJ. 2011;343:d5928. PubMed ID: 22008217 doi:10.1136/bmj.d5928

18. Faraut B, Giannesini B, Matarazzo V, et al. Capsiate administration results in an uncoupling protein-3 downregulation, an enhanced muscle oxidative capacity and a decreased abdominal fat content in vivo. Int $J$ Obes. 2009;33(12):1348-1355. doi:10.1038/ijo.2009.182

19. Kazuya Y, Tonson A, Pecchi E, et al. A single intake of capsiate improves mechanical performance and bioenergetics efficiency in contracting mouse skeletal muscle. Am J Physiol Endocrinol Metab. 2014;306(10):E1110-E1119. PubMed ID: 24644244 doi:10.1152/ ajpendo.00520.2013

20. Faraut B, Giannesini B, Matarazzo V, et al. Downregulation of uncoupling protein-3 in vivo is linked to changes in muscle mitochondrial energy metabolism as a result of capsiate administration. Am J Physiol Endocrinol Metab. 2007;292(5):E1474-E1482. PubMed ID: 17264228 doi:10.1152/ajpendo.00292.2006

21. Luo Z, Ma L, Zhao Z, et al. TRPV1 activation improves exercise endurance and energy metabolism through PGC-1 $\alpha$ upregulation in mice. Cell Res. 2012;22(3):551-564. PubMed ID: 22184011 doi:10. 1038/cr.2011.205

22. Dousset E, Marqueste T, Decherchi P, Jammes Y, Grelot L. Effects of neonatal capsaicin deafferentation on neuromuscular adjustments, 
performance, and afferent activities from adult tibialis anterior muscle during exercise. J Neurosci Res. 2004;76(5):734-741. PubMed ID: 15139032 doi:10.1002/jnr.20110

23. Ohyama K, Nogusa Y, Suzuki K, Shinoda K, Kajimura S, Bannai M. A combination of exercise and capsinoid supplementation additively suppresses diet-induced obesity by increasing energy expenditure in mice. Am J Physiol Endocrinol Metab. 2015;308(4):E315-E323. PubMed ID: 25516550 doi:10.1152/ajpendo.00354.2014

24. Hsu YJ, Huang WC, Chiu CC, et al. Capsaicin supplementation reduces physical fatigue and improves exercise performance in mice. Nutrients. 2016;8(10):648. doi:10.3390/nu8100648

25. Yashiro K, Tonson A, Pecchi É, et al. Capsiate supplementation reduces oxidative cost of contraction in exercising mouse skeletal muscle in vivo. PLoS One. 2015;10(6):e0128016. PubMed ID: 26030806 doi:10.1371/journal.pone.0128016

26. Kim KM, Kawada T, Ishihara K, Inoue K, Fushiki T. Increase in swimming endurance capacity of mice by capsaicin-induced adrenal catecholamine secretion. Biosci Biotechnol, Biochem. 1997;61(10): 1718-1723. doi:10.1271/bbb.61.1718

27. Kim KM, Kawada T, Ishihara K, Inoue K, Fushiki T. Swimming capacity of mice is increased by oral administration of a nonpungent capsaicin analog, stearoyl vanillylamide. J Nutr. 1998;128(11):19781983. PubMed ID: 9808652 doi:10.1093/jn/128.11.1978

28. Kim KM, Kawada T, Ishihara K, Inoue K, Fushiki T. Inhibition by a capsaicin antagonist (capsazepine) of capsaicin-induced swimming capacity increase in mice. Biosci Biotechnol, Biochem. 1998;62(12): 2444-2445. doi:10.1271/bbb.62.2444

29. Oh TW, Ohta F. Capsaicin increases endurance capacity and spares tissue glycogen through lipolytic function in swimming rats. $J$ Nutr Sci Vitaminol. 2003;49(2):107-111. PubMed ID: 12887156 doi: 10.3177/jnsv.49.107

30. Oh TW, Oh TW, Ohta F. Dose-dependent effect of capsaicin on endurance capacity in rats. Br J Nutr. 2003;90(3):515-520. PubMed ID: 13129456 doi:10.1079/BJN2003919

31. de Freitas MC, Cholewa JM, Gobbo LA, de Oliveira J, Lira FS, Rossi FE. Acute capsaicin supplementation improves 1500-m running timetrial performance and rate of perceived exertion in physically active adults. J Strength Cond Res. 2018;32(2):572-577. doi:10.1519/JSC. 0000000000002329

32. Costa LA, Freitas MC, Cholewa JM, et al. Acute capsaicin analog supplementation improves $400 \mathrm{~m}$ and $3000 \mathrm{~m}$ running time-trial performance. Int J Exerc Sci. 2020;13(2):755-765. PubMed ID: 32509117

33. Padilha CS, Billaut F, Figueiredo C, Pannissa VLG, Rossi FE, Lira FS. Capsaicin supplementation during high-intensity continuous exercise: a double-blind study. Int J Sports Med. 2020; 41:1-6.

34. Langan SP, Grosicki GJ. Commercially available capsaicin supplement fails to enhance time-to-exhaustion during cycling. Int $J$ Exerc Sci. 2020;13(2):225-233. PubMed ID: 32148618

35. Lebovitz EE, Keller JM, Kominsky H, Kaszas K, Maric D, Iadarola MJ. Positive allosteric modulation of TRPV1 as a novel analgesic mechanism. Mol Pain. 2012;8:70. PubMed ID: 22998799 doi:10. 1186/1744-8069-8-70

36. Lotteau S, Ducreux S, Romestaing C, Legrand C, Van Coppenolle F. Characterization of functional TRPV1 channels in the sarcoplasmic reticulum of mouse skeletal muscle. PLoS One. 2013;8(3):e58673. PubMed ID: 23536811 doi:10.1371/journal.pone.0058673

37. Whiting S, Derbyshire E, Tiwari B. Could capsaicinoids help to support weight management? A systematic review and meta-analysis of energy intake data. Appetite. 2014;73:183-188. PubMed ID: 24246368 doi:10.1016/j.appet.2013.11.005
38. Basith S, Cui M, Hong S, Choi S. Harnessing the therapeutic potential of capsaicin and its analogues in pain and other diseases. Molecules. 2016;21(8):966. doi:10.3390/molecules21080966

39. Fattori V, Hohmann MS, Rossaneis AC, Pinho-Ribeiro FA, Verri WA. Capsaicin: current understanding of its mechanisms and therapy of pain and other pre-clinical and clinical uses. Molecules. 2016; 21(7):844. doi:10.3390/molecules21070844

40. Cè E, Longo S. Peripheral fatigue: new mechanistic insights from recent technologies. Eur J Appl Physiol. 2020;120(1):17-39. PubMed ID: 31745629 doi:10.1007/s00421-019-04264-w

41. Asp ML, Martindale JJ, Heinis FI, Wang W, Metzger JM. Calcium mishandling in diastolic dysfunction: mechanisms and potential therapies. Biochim Biophys Acta. 2013;1833(4):895-900. PubMed ID: 23022395 doi:10.1016/j.bbamcr.2012.09.007

42. Sunnerhagen KS, Grimby G. Muscular effects in late polio. Eur J Appl Physiol. 2001;171(3):335-40. doi:10.1046/j.1365-201x.2001. 00836.x

43. Shintaku K, Uchida K, Suzuki Y, et al. Activation of transient receptor potential A1 by a non-pungent capsaicin-like compound, capsiate. Br J Pharmacol. 2012;165(5):1476-1486. PubMed ID: 21883144 doi:10.1111/j.1476-5381.2011.01634.x

44. Yang F, Xiao X, Lee BH, et al. The conformational wave in capsaicin activation of transient receptor potential vanilloid 1 ion channel. Nat Commun. 2018;9(1):2879. PubMed ID: 30038260 doi:10.1038/ s41467-018-05339-6

45. Linari M, Brunello E, Reconditi M, et al. Force generation by skeletal muscle is controlled by mechanosensing in myosin filaments. Nature. 2015;528(7581):276-279. PubMed ID: 26560032 doi:10.1038/ nature 15727

46. Silveira PE, Silveira NA, de Cássia Morini V, Kushmerick C, Naves LA. Opposing effects of cannabinoids and vanilloids on evoked quantal release at the frog neuromuscular junction. Neurosci Lett. 2010;473(2): 97-101. PubMed ID: 20176082 doi:10.1016/j.neulet.2010.02.026

47. Ørtenblad N, Westerblad H, Nielsen J. Muscle glycogen stores and fatigue. J Physiol. 2013;591(18):4405-4413. PubMed ID: 23652590 doi:10.1113/jphysiol.2013.251629

48. Stellingwerff T, Cox GR. Systematic review: carbohydrate supplementation on exercise performance or capacity of varying durations. Appl Physiol Nutr Metab. 2014;39(9):998-1011. PubMed ID: 24951297 doi:10.1139/apnm-2014-0027

49. Zsiborás C, Mátics R, Hegyi P, et al. Capsaicin and capsiate could be appropriate agents for treatment of obesity: a meta-analysis of human studies. Crit Rev Food Sci Nutr. 2018;58(9):1419-1427. PubMed ID: 28001433 doi:10.1080/10408398.2016.1262324

50. Stinson C, Logan SM, Bellinger LL, Rao M, Kinchington PR, Kramer PR. Estradiol acts in lateral thalamic region to attenuate varicella zoster virus associated affective pain. Neuroscience. 2019;414:99 111. PubMed ID: 31271831 doi:10.1016/j.neuroscience.2019.06.029

51. Slavich GM, Sacher J. Stress, sex hormones, inflammation, and major depressive disorder: extending social signal transduction theory of depression to account for sex differences in mood disorders. Psychopharmacology. 2019;236(10):3063-3079. PubMed ID: 31359117 doi:10.1007/s00213-019-05326-9

52. Rogers J, Urbina SL, Taylor LW, et al. Capsaicinoids supplementation decreases percent body fat and fat mass: adjustment using covariates in a post hoc analysis. BMC Obes. 2018;5(1):22. PubMed ID: 30123516 doi:10.1186/s40608-018-0197-1

53. Urbina SL, Roberts MD, Kephart WC, et al. Effects of twelve weeks of capsaicinoid supplementation on body composition, appetite and self-reported caloric intake in overweight individuals. Appetite. 2017;113:264-273. PubMed ID: 28235621 doi:10.1016/j.appet. 2017.02.025 